\title{
Obituary
}

\section{PROFESSOR DR ICHIRO SUNAGAWA}

\section{August 1924-20 December 2012}

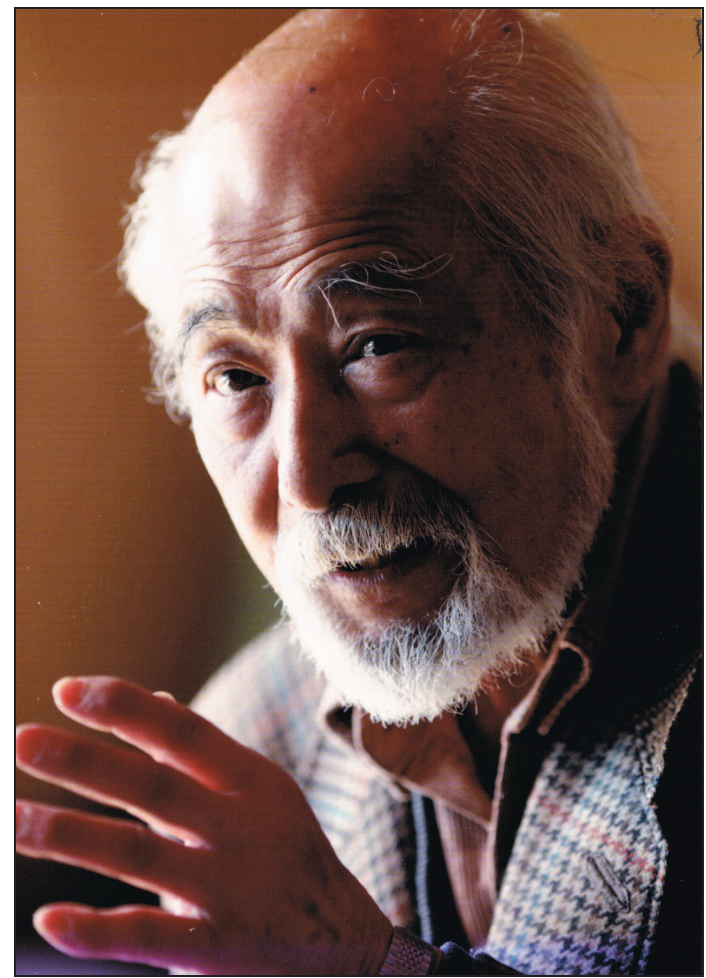

It is with deep sadness that we record the death of Professor Ichiro Sunagawa, who died from pneumonia on 20 December 2012. He was born in Hamamatsu although his family 'clan' had long lived in the village which gave rise to the family name - Sunagawa-machi (now renamed Kashiwacho, situated in the city of Tachikawa, west of Tokyo). Professor Sunagawa was educated at Tohoku Imperial University, gaining a BSc in mineralogy and then joined the Japanese Geological Survey in 1948 as a researcher. In 1957 he was awarded a PhD by Hokkaido University for his thesis 'Morphological variations in pyrite'. Still working for the Geological Survey, he was granted time at Royal Holloway College, University of London, from 1957 to 1960 to conduct a study of the surface structures of hematite and silicon carbide. In 1963 he was awarded the Geological Society of Japan prize for 'Study on the surface structures of crystals' based on this work.

In August 1971 he was appointed Professor of Tohoku University in charge of the Department of Minerals and remained in post until March 1988 when he was awarded the title Professor Emeritus.

His research activities continued unabated, and in March 1991 he was head of the Organizing Committee of the 9th International Conference in Crystal Growth for its meeting in Japan. Also in 1991 he became Principal of the Yamanashi Institute of Gemmology and Jewellery Arts and served until his retirement in 2005. 


\section{PROFESSOR DR ICHIRO SUNAGAWA}

In endeavouring to understand the kinetic processes taking place at atomic and molecular levels, he researched their effects on crystalline form, homogeneity, integrity and aggregation from simple systems to those as complex as those in the organic world. He then applied the basic theories and insights obtained to problems in gemmology and mineral exploration. As such, he played the role of a pioneer, developing the new discipline of crystal growth studies, and helping found the Japan Association for Crystal Growth.

Professor Sunagawa also founded the Gemmological Association of Japan and, from 1991 to the present, served as an Examiner for The Gemmological Association of Great Britain and was an Associate Editor of The Journal of Gemmology - he was a major influence in establishing the high standard of gemmology in Japan through support for education and the spread of local qualifications and the FGA. His international honorary awards include a doctorate from the University of Marseilles, France (for research on crystal growth mechanisms in minerals) in 1982, and Foreign Member of the Bulgarian Academy of Sciences in 1989, and he also held membership of the Russian Mineralogical Society, the Bulgarian Geological Society, the Mineralogical Society of Great Britain and Ireland, and the Korean Society of Crystal Growth; he was a member with honour of the Mineralogical Society of Japan.

He loved minerals from his schooldays until the end of his life and shared this love with his many international friends.

Farewell Professor Sunagawa, you will be sadly missed.

TAKESHI MiYATA

This obituary is reproduced with the kind permission of Gem-A, the Gemmological Association of Great Britain. 